\title{
The Effects of Organizational Cynicism on Job Attitudes an Empirical Study on Teaching Hospitals in Egypt
}

\author{
Wageeh A. Nafei ${ }^{1}$ \\ ${ }^{1}$ University of Sadat City, Menoufia, Egypt \\ Correspondence: Wageeh A. Nafei, University of Sadat City, Menoufia, Egypt. Tel: 11-20-100-019-2097. \\ E-mail: dr.wageeh1965@yahoo.com
}

Received: May 17, 2013

Accepted: June 3, $2013 \quad$ Online Published: June 14, 2013

doi:10.5539/ibr.v6n7p52

URL: http://dx.doi.org/10.5539/ibr.v6n7p52

\begin{abstract}
The present study examines the effects of organizational cynicism on two dimensions of job attitudes (organizational commitment and job satisfaction). Over the years, much work has been done by researchers who focused on organizational commitment and job satisfaction. Drawing on the literature review, there are some studies regarding organizational cynicism. In Egypt, limited research has been conducted, but the present study attempts to find out whether there is a relationship between organizational cynicism and job attitudes. Teaching Hospitals in Egypt were our subject matter from 2012/9 through 2013/2, to be a pioneering study on organizational cynicism and its effect on job attitudes. This survey-type research is descriptive in terms of the data collection. The present study investigates the attitudes of employees in regards to organizational cynicism, organizational commitment, and job satisfaction. Ultimately, it elucidates the effect of organizational cynicism on job attitudes. Three groups of employees at Teaching Hospitals in Egypt were examined. Three hundred and fifty seven questionnaires were distributed and 297 usable questionnaires were returned, a response rate of $83 \%$. The results reveal that there are differences among the three groups of employees based upon their evaluative attitudes towards organizational cynicism, organizational commitment and job satisfaction. The present study provides a number of recommendations for managers and practitioners to consider. Finally, the implications of this study are discussed.
\end{abstract}

Keywords: organizational cynicism, job attitudes

\section{Introduction}

Organizational Cynicism is an attitude that involves unfriendliness oneself from the organization due to a confidence that the organization lacks honesty and will always attempt to fool its employees (Nair \& Kamalanabhan, 2010). It is an individual negative feeling, such as disturbance, dissatisfaction and hopelessness about the staff and organization (Özler et al., 2011).

Organizational cynicism is an outcome of an employees' belief that organizations lack honesty. More specifically, expectations of morality, justice, and honesty are violated. Over the years, researchers have become more interested on issues relating to organizational cynicism. The concept of cynicism has become the subject of various disciplines in social sciences like philosophy, religion, political science, sociology, management and psychology (Ince \& Turan, 2011).

It should be mentioned that studies regarding cynicism in Egypt are novel and in its rudimentary stages. Consequently, theoretical and empirical studies on this important topic are needed to better understand the short-term and long-term implications on organizations. For the purpose of this study, cynicism is defined as an employee having negative feelings such as anger, disappointment, and hopelessness. Ultimately, numerous problems emerge for both staff and organizations (Özler et al., 2010).

The importance of organizational cynicism in the Arab environments has not received its due share of interest. The relationship between organizational cynicism and job attitudes has not been thoroughly investigated. Therefore, the current study is trying to examine the attitudes of employees toward organizational cynicism at Teaching Hospitals in Egypt and its effects on job attitudes.

Organizational commitment and job satisfaction are key job attitudes (Dewettinck \& Van Ameijde, 2011). It should be mentioned that researchers have focused on the correlation between organizational commitment and 
job satisfaction and have been able to conclude that job satisfaction leads to organizational commitment (Lane et al., 2010).

This elucidates the relationship between organizational cynicism and job attitudes, particularly in the Egyptian context.

This study is structured as follows: Section two presents the literature review. Section three presents the research questions and hypotheses. Section four explains the research strategy. Empirical results are provided in section five. Section six handles the main findings. Recommendations for dealing with organizational cynicism are presented in section seven. Finally, the implications of this study are discussed.

\section{Literature Review}

Hereunder is an overview of different contributions in literature regarding (1) organizational cynicism, and (2) job attitudes.

\subsection{Organizational Cynicism}

Cynicism can be described as being negative and pessimistic about others. Employees who are cynical can influence the entire organization and can hinder the organization from reaching its goals. Cynical employees believe that their colleagues are selfish and self-centered (Barefoot et al., 1989).

Some factors that influence cynicism are: dealing with stress, disagreement with organizational expectations, lack of social support and recognition, not having a voice in the decision-making process, unbalanced distribution of power, and lack of communication (Reichers et al., 1997).

Cynics also believe that employees have low-levels of critical thinking capabilities and are not worthy of trust or loyalty (Abraham, 2000).

It should be mentioned that some researchers believe that cynicism is a personality trait or attitude rather than a lifestyle (Özgener et al., 2008).

To sum up, cynicism has become the norm in many organizations in the US and may also be the case in Egypt and other countries around the world. Some may argue that this is a direct result to job satisfaction levels decreasing over the last decade. One survey showed that just $49 \%$ of Americans are satisfied with their jobs, down from $58 \%$ a decade ago (Koretz, 2003). With job satisfaction levels decreasing and organizational cynicism increasing, it becomes imperative for managers to develop strategies to prevent such behaviors because they are considered to be contagious.

Organizational cynicism can be defined as general or specific attitudes of disappointment, insecurity, hopelessness, anger, mistrust of institutions or persons, group, ideology and social skills (Andersson, 1996).

It is the belief that an organization lacks honesty causing hard-hitting reputation and critical behaviors when it is combined with a strong negative emotional reaction (Abraham, 2000).

Organizational cynicism is an estimation based on an individual's work experience of the evaluator (Cole et al., 2006).

It may refer to being unsatisfied with the organization. This conditions with the tenets of sincerity, honesty, fairness and lack of the moral integrity in organizations (Bernerth et al., 2007).

Organizational cynicism is defined as an attitude formed by faith, feelings and behavioral tendencies. It is a negative attitude including the three dimensions developed by a person to his organization, namely; cognitive, affective, and behavioral structure of the cynical construct (Dean et al., 1998; Stanley et al., 2005).

- The cognitive dimension of organizational cynicism is the belief in the organization's lack of honesty. It is the belief that the organization's practices lack justice, honesty and sincerity. Cynics believe that those principles are mostly forfeited. They are replaced by unprincipled actions and immoral attitudes as if they are norms. Besides, cynics may believe that human beings are untrustworthy and incoherent in their behaviors.

- The affective dimension of organizational cynicism refers to the emotional/sentimental reactions to the organization. The sensitive/emotional consists of strong emotional reactions towards the organization. Cynics may feel disrespect and anger towards their organizations; or feel discomfort, hatred and even shame when they think about their organizations. Thus, cynicism is related to various negative senses.

- The behavioral dimension of organizational cynicism refers to negative tendencies and mainly humiliating attitudes. This dimension consists of negative and frequently critical attitudes. Strong critical expressions towards the organization are the most prominent of behavioral tendencies. These may occur in various forms, 
mostly expressions about the organization's lack of honesty and sincerity.

Dean et al. (1998) have synthesized these dimensions into their definition of organizational cynicism as (1) a belief that the organization lacks integrity; (2) negative affect toward the organization; and (3) tendencies to disparaging and critical behaviors toward the organization that are consistent with these beliefs and effects.

\subsection{Job Attitudes}

Two important aspects of job attitudes are organizational commitment and job satisfaction (Yang \& Mossholder, 2010; Chang et al., 2010). Job satisfaction and organizational commitment are positively related (Boles et al., 2007). Job satisfaction is a multi-dimensional and complex phenomenon (Fisher \& Locke, 1992), Job satisfaction is influenced by organizational commitment (Vidal, et al., 2007).

Organizational commitment can be regarded as a predicting factor of job satisfaction that significantly predicts organizational commitment (LaLopa, 1997). Organizational commitment predicts job satisfaction; some contend that job satisfaction is a predictor of organizational commitment (Babakus et al., 1999).

Mowday et al. (1982) describe organizational commitment and job satisfaction differently. While job satisfaction is a kind of response to a specific job or job-related issue, organizational commitment is a more global response to an organization. Therefore, organizational commitment should generate more consistency than job satisfaction over time and lasts longer after one is satisfied with his/her job.

Organizational commitment and job satisfaction differ mainly in the following (1) organizational commitment can be defined as the emotional responses that an employee has toward his organization; and (2) job satisfaction is the responses that an employee has toward any job. These two variables are highly interrelated as an employee may have positive feelings toward the organization, its values and objectives, but he or she may be unsatisfied with his or her job in the organization (Meyer et al., 2002).

Job satisfaction and employee commitment are proven empirically to have a strong correlation (Riggio, 2009). Namasivayama and Zhaob (2007) enhance evidence to the organizational commitment impact on job satisfaction (Yang, 2009).

There are three relationships among organizational commitment, job satisfaction and employee turnover intentions as follows (1) job satisfaction impact on organizational commitment virtually affects employee turnover, (2) job satisfaction plays the role of a mediator between organizational commitment and turnover intention, and (3) impact of job satisfaction and organizational commitment on each other and their affect on turnover intention (Wong et al., 2001).

Organizational commitment and job satisfaction are interrelated; they have diverse attitudes. Organizational commitment is the better means of constancy, belonging and permanence compared to job satisfaction (Lane et al., 2010).

\subsubsection{Organizational Commitment}

Mowday et al. (1982) conceive commitment as an attitude reflecting the nature and quality of the linkage between an employee and an organization. It is an individual's identification with a particular organization and its goals to maintain membership in order to attain these goals.

Organizational commitment has been defined as an employee's connection and loyalty to a particular organization (Porter et al., 1976; Mowday et al., 1979).

It refers to an employee's willingness to exert extra effort within the organization (Batemen \& Strasser, 1984).

Organizational commitment is a feeling of dedication, willingness to go the extra mile, and an intention to stay with the organization for a long period of time (Meyer \& Allen, 1988; 1991). It means loyalty and intention to stay with the organization (Brewer, 1996).

It is beneficial for the organization as it reduces the absenteeism rate and turnover ratio, let alone enhancing the organization's productivity (Jernigan et al., 2002).

Organizational commitment is interested in the employee's willingness to leave their organization (Greenberg \& Baron, 2003).

It reflects the work attitudes of employees toward the organizations in which they work (Silverthorne, 2004). It is an individual's willingness to dedicate efforts and loyalty to an organization (Wagner, 2007).

Organizational commitment described as a key factor in the relationship between individuals and organizations (Sharma \& Bajpai, 2010). 
The three components conceptualization of organizational commitment indicated by Meyer and Allen (1991) are as follows:

- Affective commitment refers to an employee's continuing to work for an organization thanks to emotional attachment to, involvement in, and identification with that organization.

- Continuance commitment refers to the commitment based on the costs that are associated with leaving a specific organization.

- Normative commitment relates to feeling obligated to remain with an organization, i.e. an employee with a strong sense of normative commitment will feel obligated to stay in the organization because the organization invested a lot of time to train the employee.

Meyer and Allen (1991) believe that employees can experience all three forms of commitment and that the psychological states reflecting the three components of organizational commitment will develop as the function of quite different antecedents. They will also have different implications for work behavior. Most managers would agree that it is very difficult to find employees who have both high levels of task performance and organizational commitment.

Griffeth et al. (1999) developed a model recognizing the four types of employees: stars, citizens, lone wolves, and apathetics in an organization. According to Kaifi (2013), stars possess high organizational commitment levels and also high task performance levels. Citizens possess high organizational commitment levels and low task performance levels. Lone wolves possess low levels of organizational commitment levels but high levels of task performance levels. Apathetics possess low levels of organizational commitment and task performance.

Raju and Srivastava (1994) believe that organizational commitment can be described as the factor that promotes the attachment of the individual to the organization. To put it differently, higher levels of performance and effectiveness at both the individual and the organizational level will be the outcome of the high levels of effort exerted by employees with high levels of organizational commitment.

\subsubsection{Job Satisfaction}

Job satisfaction is the feelings one has toward a job and its various aspects. It has to do with how one feels about his or her job (Rahim, 1982). It is the degree of favorableness with which employees view their work (Stewart, 1983).

Job satisfaction means how much people like (satisfaction) or dislike (dissatisfaction) their jobs (Spector, 1997). It refers to the positive feelings that employees have towards their jobs (Schermerhorn et al., 1997). It includes employee's overall affective state regarding estimation of all aspects of his or her job (Netemeyer et al., 1997).

Job satisfaction is the pleasure gained from the assessment of one's job regarding the realization of job values (Schwepker, 2001). It means how far the employee is satisfied with his present work taking into account satisfaction of many of his needs and wants (Finn, 2001). An employee's emotional attitude toward his or her job is the core of job satisfaction (Price, 2001).

Job satisfaction is the degree of an individual's satisfaction with the internal or external aspects of his or her job (Bhuian \& Menguc, 2002). It is detected and assessed in accordance to one's total feeling about their job and the attitudes toward various sides or facets of their job (Ivancevich \& Matteson, 2002). It stems from one's envision of their job under the influence of their own unique needs, values and expectations. These factors are highly esteemed by them (Sempane et al., 2002). It is the reaction to a job, regarding one's targets in a job in comparison with the actual outcomes that the job provides to the individual (Rothmann \& Coetzer, 2002).

Job satisfaction means personal gratification from one's work, as well as pleasure and feeling of accomplishment employees derive from performing their jobs well (Elbert \& Griffin, 2005).

Job satisfaction is of interest for workers in organizations and those studying them. It is a salient variable in organizational behavior research, as well as theory of organizational experience ranging from job design to supervision (Hong et al., 2005).

Job satisfaction draws on the nature of the job, besides the expectation of an employee from the job (Hussami, 2008). The assessment of one's job has a lot to do with one's values and what they are motivated by (Yang 2009).

There are two main reasons for concern regarding job satisfaction (1) association of low levels of job satisfaction with low levels of satisfaction with life, poor mental well-being, and even poor physical health; (2) individuals get affected by job satisfaction in the workplace. This is because the negative effects of low levels of satisfaction 
may increase turnover, absenteeism, tardiness, decreased professional commitment, and lower quality of work (Noel, et al., 1982).

The two-factor theory of job satisfaction influentially explains job satisfaction. It maintains that job satisfaction has two components: intrinsic job factors and extrinsic job factors. Intrinsic job factors refer to an employee's desire for recognition, acceptance, responsibility, and advancement. Extrinsic job factors refer to satisfaction with salary, company mission and policies, and working conditions (Deselle, 1998). Thus, conditions at work trigger one of the needs. Work conditions related to satisfaction were labeled motivation factors. Work conditions related to dissatisfaction were labeled hygiene factors (Kaifi, 2013).

Job satisfaction is a sign of organizational effectiveness as most employers realize that the optimal functioning of their organization depends partially on their level of job satisfaction (Saari \& Judge, 2004). Optimal performance needs employee's full potential at all levels in organizations; this emphasizes the importance of employee job satisfaction (Rothmann \& Coetzer, 2002).

\section{Research Questions and Hypotheses}

The research process includes both questions and hypotheses. The research questions of this study are as follows: Q1: Are there essential variations among the employees at Teaching Hospitals in Egypt towards organizational cynicism?

Q2: Are there fundamental differences among the employees at Teaching Hospitals in Egypt towards organizational commitment?

Q3: Are there fundamental variations among the employees at Teaching Hospitals in Egypt towards job satisfaction?

Q4: What is the effect of organizational cynicism on organizational commitment at Teaching Hospitals in Egypt?

Q5: What is the relationship between organizational cynicism and job satisfaction at Teaching Hospitals in Egypt?

Drawing on these research questions, the research hypotheses of this study are as follows:

H1: There is no significant discrimination among the employees at Teaching Hospitals in Egypt towards organizational cynicism.

H2: There is no significant differences among the employees at Teaching Hospitals in Egypt towards organizational commitment.

H3: There is no significant discrimination among the employees at Teaching Hospitals in Egypt towards job satisfaction.

H4: There is no relationship between organizational cynicism and organizational commitment at Teaching Hospitals in Egypt.

H5: There is no relationship between organizational cynicism and job satisfaction at Teaching Hospitals in Egypt.

\section{Research Strategy}

A survey was used for the research design to collect data directly from the subject under review. Responses are then analyzed and hypotheses are tested for accuracy and correlations.

\subsection{Population and Sample}

The research study attempts to investigate the effects of organizational cynicism on job attitudes at Teaching Hospitals in Egypt. This sector includes nine Hospitals. They are Ahmed Maher, El-Matrya, El-Galaa, El-Sahel, Benha, Shebin El-Kom, Damnhour. The researcher excludes Hospitals in Sohag and Aswan. This explains why the population of this study includes 5,135 employees.

The random sampling was used for collecting the primary data due to difficulty of having access to all of the items of the research population, because of time limitations. The stratified random sample was used while selecting items from the different categories of employees. The following equation determines the sampling size (Daniel, 1999):

$$
\mathrm{n}=\frac{N \times(Z)^{2} \times P(1-P)}{d^{2}(N-1)+(Z)^{2} \times P(1-P)}
$$


Accordingly, the sample size has become 357 employees at Teaching Hospitals in Egypt.

Table 1. Distribution of the sample size

\begin{tabular}{llll}
\hline Job Category & Number of Population & Percentage & Sample Size \\
\hline Physicians & 1926 & $37.50 \%$ & 357 X $37.50 \%=134$ \\
Nurses & 2714 & $52.86 \%$ & $357 \times$ X 52.86\%=189 \\
Administrative Staff & 495 & $9.64 \%$ & $357 \times$ X $9.64 \%=34$ \\
Total & $\mathbf{5 1 3 5}$ & $\mathbf{1 0 0 \%}$ & $\mathbf{3 5 7} \mathbf{X} \mathbf{1 0 0} \%=\mathbf{3 5 7}$ \\
\hline
\end{tabular}

Source: Personnel Department at Teaching Hospitals in Egypt, 2013.

Table 1 proves proportionality with the number of employees in the research population. Virtually, random choice of categories was accomplished utilizing the lists of employees at the Staff Affairs Department, Teaching Hospitals in Egypt. Table 2 illustrates the characteristics of sample units.

Table 2. Frequency distribution of the features of the sample

\begin{tabular}{|c|c|c|c|}
\hline Variables & & Frequency & Percentage \\
\hline \multirow[t]{4}{*}{ 1- Job Title } & Physicians & 84 & $28.3 \%$ \\
\hline & Nurses & 183 & $61.6 \%$ \\
\hline & Administrative Staff & 30 & $10.1 \%$ \\
\hline & Total & 297 & $100 \%$ \\
\hline \multirow[t]{3}{*}{ 2- Sex } & Male & 119 & $40.1 \%$ \\
\hline & Female & 178 & $59.9 \%$ \\
\hline & Total & 297 & $100 \%$ \\
\hline \multirow[t]{3}{*}{ 4- Marital Status } & Single & 142 & $47.8 \%$ \\
\hline & Married & 155 & $52.2 \%$ \\
\hline & Total & 297 & $100 \%$ \\
\hline \multirow[t]{4}{*}{ 5- Age } & Under 30 & 171 & $57.6 \%$ \\
\hline & From 30 to 45 & 105 & $35.4 \%$ \\
\hline & Above 45 & 21 & $7.1 \%$ \\
\hline & Total & 297 & $100 \%$ \\
\hline \multirow[t]{4}{*}{ 6- Educational Level } & Secondary school & 160 & $53.9 \%$ \\
\hline & University & 102 & $34.3 \%$ \\
\hline & Post Graduate & 35 & $11.8 \%$ \\
\hline & Total & 297 & $100 \%$ \\
\hline \multirow[t]{4}{*}{ 6- Period of Experience } & Less than 5 years & 124 & $41.8 \%$ \\
\hline & From 5 to 10 & 98 & $33.0 \%$ \\
\hline & More than 10 & 75 & $25.3 \%$ \\
\hline & Total & 297 & $100 \%$ \\
\hline
\end{tabular}

\subsection{Procedure}

Questionnaires are used to recognize organizational cynicism, organizational commitment and job satisfaction. The questionnaire included three pages. A covering letter was attached to the questionnaire, explaining the aim of the study to reassure respondents of the confidentiality of responses and give instructions for completing the questionnaire.

Only 25 questionnaires were piloted by a closed circle of employees, requiring some modification. Data collection was accomplished through contacting informants in informal interviews. The questionnaires were distributed to all respondents in the sample to be completed anonymously during group administration.

The questionnaire included three types of questions, relating to recognizing organizational cynicism, organizational commitment, job satisfaction, A questionnaire on biographical information was included, containing questions on the variables of job title, sex, marital status, age, educational level, and period of experience. Data collection took approximately two months. Survey responses were 83\%, 297 completed surveys out of the 357 distributed. 


\subsection{Measuring Instruments}

\subsubsection{Organizational Cynicism}

In this study, the independent variable is organizational cynicism. The researchers utilize the scale of Dean et al., (1998), Brandes, et al., (1999) and Kalağan (2009) for measuring organizational cynicism. Organizational Cynicism Scale (OCS) is comprised of the three dimensions of affect, cognition, and behavior. The affect items reflect negative emotions such as distress-anguish, anger-rage, and disgust-revulsion. Belief items reflect cognitive evaluations that employees have about the integrity and sincerity of their employing organization. Behavioral items reflect critical and disparaging behaviors associated with organizational cynicism. OCS consists of 13 statements. There are five statements in cognitive dimension, four statements in emotional dimension and four statements in behavioral dimension. Organizational cynicism has been measured by the five-item scale of Likert of (Completely Agree) to (Completely Disagree) where each statement has five options.

\subsubsection{Organizational Commitment}

Organizational commitment, as a dependent variable, has been tackled. Aspects of organizational commitment include affective, continuance, and normative commitment. The researcher has employed the measure developed by Allan and Meyer (1990), modified by Meyer, et. al. (1993), to measure organizational commitment. It consists of 18 statements equally divided among secondary measures. A Likert scale was used for judging levels of agreement or disagreement, ranging from (5) which refers to full agreement and (1) which refers to full disagreement. This measure is used in many studies like Meyer, et al (1993) and Dunham, et al. (1994).

\subsubsection{Job Satisfaction}

Job satisfaction, as a dependent variable, has been investigated. The study has measured job satisfaction as a composite index of response to five statements taken from an eighteen item as tested by Agho, et al. (1993). The validity and reliability of the five statements have been demonstrated by Price \& Mueller $(1981 ; 1986)$ and by Hardigan \& Carvajal (2001). The questionnaire used the five-point Likert scale ranging from (1), strongly disagree, to (5) strongly agree.

\subsubsection{Data Analysis and Testing Hypotheses}

The researcher has employed the following methods: (1) the Alpha Correlation Coefficient (ACC), which aims at verifying the degree of reliability in the scale of organizational cynicism and job attitudes, (2) Multiple Discriminant Analysis (MDA), which aims at discriminating among the employees in regard to organizational cynicism and job attitudes, (3) Multiple Regression Analysis (MRA), which aims at verifying the type and strength of the relationship between organizational cynicism as independent variables and job attitudes as a dependent variable, and (4) the statistical testing of hypotheses which includes Wilk's Lambda and chi-square that goes hand in hand with the MDA and F-test and T-test which go hand in hand with the MRA. All these tests accompany analysis means which are to be used. They are found in SPSS.

\section{Hypotheses Testing}

Findings will be explained as follows (1) reliability of scales, (2) organizational cynicism, (3) organizational commitment, (4) job satisfaction, (5) the relationship between organizational cynicism and organizational commitment, and (6) the relationship between organizational cynicism and job satisfaction.

\subsection{Evaluating Reliability}

The reliability of organizational cynicism, organizational commitment and job satisfaction were assessed to reduce errors of measuring and maximizing constancy of these scales.

ACC was used to determine the reliability or the degree of internal consistency in the scale under testing. It was decided to exclude variables that had a correlation coefficient of less than 0.30 when the acceptable limits of ACC range from 0.60 to 0.80 . Levels of reliability analysis in social sciences so decide.

Table 3. Reliability of organizational cynicism

\begin{tabular}{lll}
\hline The Dimension of Organizational Cynicism & Number of Statement & ACC \\
\hline The Cognitive Dimension & 5 & 0.65 \\
The Affective Dimension & 4 & 0.94 \\
The Behavioral Dimension & 4 & 0.63 \\
Total Measurement & $\mathbf{1 3}$ & $\mathbf{0 . 8 3}$ \\
\hline
\end{tabular}


Table 3 presents the internal consistency or reliability of the scales measured through Cronbach's alpha. The reliabilities of the cognitive and affective scales are generally higher (ranging from 0.65 to 0.94 ); while the behavioral scale is at 0.63 , still indicating high reliability. The overall reliability of the preferred organizational questionnaire is 0.83 , proving that organizational cynicism scale is reliable.

Table 4. Reliability of organizational commitment

\begin{tabular}{lll}
\hline The Dimension of Organizational Commitment & Number of Statement & ACC \\
\hline Affective Commitment & 6 & 0.82 \\
Continuance Commitment & 6 & 0.70 \\
Normative Commitment & 6 & 0.81 \\
Total Measurement & $\mathbf{1 8}$ & $\mathbf{0 . 8 3}$ \\
\hline
\end{tabular}

According to Table 4 the internal consistency or reliability of the preferred organizational commitment scales ranges from 0.70 to 0.82 . As a result, the overall reliability of the preferred organizational questionnaire is 0.83 , giving evidence of reliability of the organizational commitment scale.

Also, ACC was applied on the scale of job satisfaction. ACC of the scale represented about 0.89 , showing high reliability. Primary findings reflect the scale's reliability for measuring job satisfaction at Teaching Hospitals in Egypt.

Accordingly, three scales were defined, organizational cynicism (13 variables), where ACC represented about 0.83 , organizational commitment (18 variables), where ACC represented 0.83 , and job satisfaction (5 variables), where ACC represented about 0.89 .

\subsection{Organizational Cynicism}

The statistical results for the evaluative attitudes of employees towards organizational cynicism are studied. The first hypothesis to be tested is:

\section{H1: There is no discrimination among the employees at Teaching Hospitals in Egypt towards organizational cynicism.}

The MDA was applied on three groups of employees regarding their evaluative attitudes towards organizational cynicism as presented in Tables 5 and 6 .

Table 5. Multiple Discriminant Analysis (MDA) of organizational cynicism

\begin{tabular}{|c|c|c|c|c|c|c|c|c|}
\hline \multicolumn{9}{|c|}{ A- Discriminant Functions (DF) } \\
\hline Function & Eigen Values & The $\%$ of Differences & $\mathrm{MCC}$ & Wilks Lambada & Ch-Square & Degree of Sign & & Level of Sign \\
\hline 1 & 1.46 & 68.0 & 0.77 & 0.24 & 410.59 & 24 & & 0.000 \\
\hline 2 & 0.69 & 32.0 & 0.64 & 0.59 & 151.03 & 11 & & 0.000 \\
\hline \multicolumn{9}{|c|}{ B- Classification Matrix } \\
\hline \multicolumn{2}{|c|}{ Groups } & Number & \multicolumn{3}{|c|}{ Predict Member of Groups } & \multicolumn{3}{|c|}{ Total } \\
\hline \multicolumn{2}{|l|}{ Physicians } & 84 & \multicolumn{2}{|c|}{$70(83.3 \%)$} & $14(16.7 \%)$ & \multicolumn{3}{|c|}{84} \\
\hline \multicolumn{2}{|c|}{ Nurses } & 183 & \multicolumn{2}{|c|}{$15(8.2 \%)$} & $168(91.8 \%)$ & $0(0.0 \%)$ & 183 & \\
\hline \multicolumn{2}{|c|}{ Administrative Staff } & 30 & \multicolumn{2}{|c|}{$2(6.7 \%)$} & $7(23.3 \%)$ & $21(70 \%)$ & 30 & \\
\hline \multicolumn{2}{|c|}{ Total } & 297 & & & & & 297 & \\
\hline \multicolumn{9}{|c|}{ The Percentage of the exact division $87 \%$} \\
\hline
\end{tabular}

According to MDA, the most important findings include the following:

1) There is a strong significant relationship (MCC represents 0.77 in the DF) and a statistically significant relationship at level 0.01 between teaching hospitals of the employees groups and their evaluative attitudes towards organizational cynicism (see Table 5).

2) There is a high degree of difference among attitudes of employees towards organizational cynicism (the percentage of differentiation was $68 \%$ of DF).

3) The accurate classification of employees, according to their evaluative attitudes towards organizational cynicism, is $87 \%$. The remaining portion, $13 \%$, are similar (see Table 5).

4) There are twelve variables relating to organizational cynicism. They have an ability to discriminate among employees (see Table 6). The most important of them are "the employees believe that their hospital says one thing and does another (discrimination coefficients represent 0.47), "when the employees think about their 
hospital, they feel a sense of anxiety" (discrimination coefficients represent 0.28 ), "my hospital expects one thing of its employees, but rewards another" (discrimination coefficients represent 0.25 ), and "when I think about my hospital, I experience aggravation" (discrimination coefficients represent 0.25 ).

5) According to the mean of the three groups of employees (see Table 6), it was revealed that there are differences among them. As for physicians, they tend to agree, for example, that "in my hospital, I see very little resemblance between the events that are going to be done and the events which are done" (with a mean of 3.83). As for nurses, they tend to agree, for example, that "my hospital says one thing and does another" (with a mean of 4.01). As for administrative staff, they tend to agree to a high degree, for example, that "in my hospital, I see very little resemblance between the events that are going to be done and the events which are done" (with a mean of 4.47).

Accordingly, the null hypothesis is rejected because the value of Wilks Lambda amounts to 0.24 (see table 5). Moreover, the value of chi-square calculated (410.59) in the free degree of (24) exceeds its table counterpart (42.98) at the statistical significance level of 0.01 (see table 5). Furthermore, it was decided to reject the same null hypothesis of twelve variables of organizational cynicism (13 variables) at the statistical significance level of 0.01, according to the test of univariate F. (see table 6).

Table 6. The mean of employees towards organizational cynicism

\begin{tabular}{|c|c|c|c|c|c|}
\hline \multirow[t]{3}{*}{ The Variables } & \multicolumn{3}{|l|}{ Mean } & \multirow[t]{3}{*}{ F-Test } & \multirow{3}{*}{$\begin{array}{l}\text { Level } \\
\text { of Sig }\end{array}$} \\
\hline & Group & Group & Group & & \\
\hline & 1 & 2 & 3 & & \\
\hline 1. I believe that my hospital says one thing and does another. & 3.50 & 4.01 & 2.27 & $48.64^{* *}$ & 0.472 \\
\hline 2. When I think about my hospital, I feel a sense of anxiety. & 3.25 & 3.21 & 4.30 & $18.18^{* *}$ & 0.282 \\
\hline 3. My hospital expects one thing of its employees, but rewards another. & 3.33 & 3.89 & 3.90 & $6.32^{* *}$ & 0.249 \\
\hline 4. When I think about my hospital, I experience aggravation. & 3.58 & 3.22 & 4.20 & $14.19^{* *}$ & 0.249 \\
\hline $\begin{array}{l}\text { 5. We look at each other in a meaningful way with my colleagues when my hospital } \\
\text { and its employees are mentioned. }\end{array}$ & 3.08 & 3.17 & 4.40 & $15.70^{* *}$ & 0.249 \\
\hline 6. When I think about my hospital, I experience tension. & 3.42 & 3.30 & 4.30 & $12.26^{* *}$ & 0.237 \\
\hline 7. When I think about my hospital, I get angry. & 3.00 & 3.22 & 4.10 & $15.50^{* *}$ & 0.231 \\
\hline 8. I criticize the practices and policies of my hospital to people outside the hospital. & 3.17 & 2.98 & 3.90 & $9.67^{* *}$ & 0.212 \\
\hline $\begin{array}{l}\text { 9. In my hospital I see very little resemblance between the events that are going to be } \\
\text { done and the events which are done. }\end{array}$ & 3.83 & 3.84 & 4.47 & $8.22^{* *}$ & 0.187 \\
\hline 10. My hospital's policies, goals, and practices seem to have little in common & 2.50 & 2.99 & 2.23 & $9.39^{* *}$ & 0.176 \\
\hline 11. I talk with others about how work is being carried out in the hospital. & 3.00 & 3.18 & 3.90 & $7.21^{* *}$ & 0.157 \\
\hline $\begin{array}{l}\text { 12. If an application was said to be done in my hospital, I'd be more skeptical whether } \\
\text { it would happen or not. }\end{array}$ & 3.58 & 3.59 & 3.23 & 1.63 & 0.084 \\
\hline
\end{tabular}

\subsection{Organizational Commitment}

The statistical results for the evaluative attitudes of employees towards organizational commitment are judged. The second hypothesis to be tested is:

\section{H2: There is no discrimination among the employees at Teaching Hospitals in Egypt regarding organizational commitment.}

The MDA was applied on three groups of employees and their evaluative attitudes towards organizational commitment as displayed in Tables 7 and 8.

Table 7. Multiple Discriminant Analysis (MDA) of organizational commitment

\begin{tabular}{|c|c|c|c|c|c|c|c|}
\hline \multicolumn{8}{|c|}{ A- Discriminant Functions } \\
\hline Function & Eigen Values & The $\%$ of Differences & $\mathrm{MCC}$ & Wilks Lambada & Ch-Square & Degree of Sign & Level of Sign \\
\hline 1 & 1.603 & 79.1 & 0.785 & 0.270 & 376.096 & 30 & 0.000 \\
\hline 2 & 0.424 & 20.9 & 0.546 & 0.702 & 101.534 & 14 & 0.000 \\
\hline \multicolumn{8}{|c|}{ B- Classification Matrix } \\
\hline \multicolumn{2}{|c|}{ Groups } & Number & \multicolumn{3}{|c|}{ Predict Member of Groups } & \multicolumn{2}{|r|}{ Total } \\
\hline \multicolumn{2}{|l|}{ Physicians } & 84 & \multicolumn{2}{|r|}{$56(66.7 \%)$} & $21(25.0 \%)$ & $7(8.3 \%)$ & 84 \\
\hline \multicolumn{2}{|c|}{ Nurses } & 183 & \multicolumn{2}{|r|}{$38(20.8 \%)$} & $145(79.2 \%)$ & $0(0.0 \%)$ & 183 \\
\hline \multicolumn{2}{|c|}{ Administrative Staff } & 30 & \multicolumn{2}{|r|}{$1(3.3 \%)$} & $(0.0 \%)$ & $29(96.7 \%)$ & 30 \\
\hline \multicolumn{2}{|c|}{ Total } & 297 & & & & & 297 \\
\hline \multicolumn{8}{|c|}{ The Percentage of the exact division $77.4 \%$} \\
\hline
\end{tabular}


According to MDA, the most important findings include the following:

1) There is a strong significant relationship (MCC represents 0.78 in the DF) and a statistically significant relationship at level 0.01 between teaching hospitals of the employees groups and their evaluative attitudes towards organizational commitment (see Table 7).

2) There is a high degree of difference among attitudes of employees towards organizational commitment (the percentage of differentiation was $79 \%$ of DF) (see Table 7).

3) The accurate classification of employees, according to their evaluative attitudes towards organizational commitment, is $77 \%$. The rest, $23 \%$, are similar (see Table 7).

4) There are fifteen variables relating to organizational commitment. They can discriminate among employees (see Table 8), most importantly "the lack of work opportunities at other places is one of the most important reasons behind my remaining at this hospital (discrimination coefficients represent 0.38 )", "I feel strong loyalty and belonging to the family of this hospital" (discrimination coefficients represent 0.28 ), "if I do not have many things to do for myself at this hospital, I will think of working at another place" (discrimination coefficients represent 0.27 ), and "I have very few alternatives for work if I decide to leave this hospital" (discrimination coefficients represent 0.22 ).

5) According to the mean of the three groups of employees (see Table 8), differences among them emerged. As for physicians, they tend to agree, for example, that "I feel strong loyalty and belonging to the family of this hospital" (with a mean of 3.83). As for nurses, they tend to agree, for example, that "it is very difficult for me to leave work at the hospital, even if I want so" (with a mean of 3.63). As for administrative staff, they tend to agree to a high degree, for example, that "lack of work opportunities at other places is one of the most important reasons behind my remaining at this hospital" (with a mean 4.67).

Accordingly, the null hypothesis is rejected because of the value of Wilks Lambda amount to 0.27 (see table 7). Besides the value of chi-square calculated (376.096) in the free degree of (30) exceeds its table counterpart (50.89) at the statistical significance level of 0.01 (see table 7). Furthermore, it was decided to reject the same null hypothesis of fifteen variables of organizational commitment (18 variables) at the statistical significance level of 0.01, according to the test of univariate F (see table 8).

Table 8. The mean of employees regarding organizational commitment

\begin{tabular}{|c|c|c|c|c|c|}
\hline \multirow[t]{3}{*}{ The Variables } & \multicolumn{3}{|l|}{ Mean } & \multirow[t]{3}{*}{ F-Test } & \multirow{3}{*}{$\begin{array}{l}\text { Level } \\
\text { of Sig }\end{array}$} \\
\hline & Group & Group & Group & & \\
\hline & 1 & 2 & 3 & & \\
\hline $\begin{array}{l}\text { 1. Lack of work opportunities at other places is one of the most important reasons } \\
\text { behind my remaining at this hospital. }\end{array}$ & 2.75 & 2.91 & 4.67 & $40.961^{* *}$ & 0.379 \\
\hline 2. I feel strong loyalty and belonging to the family of this hospital. & 3.83 & 3.25 & 4.13 & $16.31^{* *}$ & 0.280 \\
\hline $\begin{array}{l}\text { 3. If I do not have many things to do for my self at this hospital, I will think of } \\
\text { working at another place. }\end{array}$ & 3.17 & 2.83 & 2.83 & $4.618^{* *}$ & 0.270 \\
\hline 4. I have very few alternatives for work if I decide to leave this hospital. & 2.83 & 2.97 & 4.00 & $13.220^{* *}$ & 0.218 \\
\hline 5. I owe much to this hospital. & 3.58 & 3.25 & 3.73 & $6.807^{* *}$ & 0.189 \\
\hline 6. I feel emotional relation to the hospital where I work. & 3.67 & 3.24 & 3.97 & $9.006^{* *}$ & 0.184 \\
\hline 7. I feel the problems of the hospital are really mine. & 3.33 & 3.46 & 2.77 & $6.342^{* *}$ & 0.164 \\
\hline 8. I feel I am a member of the family of this hospital. & 3.58 & 3.30 & 3.50 & 2.169 & 0.157 \\
\hline 9. My life will be highly confused if I decide to leave work at this hospital now. & 3.33 & 3.05 & 3.30 & 2.220 & 0.147 \\
\hline 10. This hospital deserves my full interest and loyalty. & 3.50 & 3.45 & 4.00 & $4.664^{* *}$ & 0.138 \\
\hline 11. It is very difficult for me to leave work at the hospital, even if I want so. & 3.67 & 3.63 & 3.07 & $4.705^{* *}$ & 0.131 \\
\hline 12. I will feel guilty if I leave work at the hospital. & 3.00 & 2.79 & 3.27 & 2.727 & 0.101 \\
\hline 13. I hope I will spend all my professional career at this hospital. & 3.08 & 2.96 & 2.77 & 0.790 & 0.094 \\
\hline 14. Continuing work at this hospital is due to my need for this for dire necessity. & 3.42 & 3.51 & 3.27 & 0.915 & 0.060 \\
\hline 15. I will not leave this hospital now as I feel I have duty towards its members. & 3.33 & 3.45 & 3.20 & 0.903 & 0.058 \\
\hline
\end{tabular}

\subsection{Job Satisfaction}

The evaluative attitudes of employees towards organizational cynicism are detected according to statistical results. The third hypothesis to be tested is:

H3: There is no discrimination among the employees at Teaching Hospitals in Egypt towards job satisfaction. 
The MDA analysis was applied on a model including three groups of employees, and their evaluative attitudes towards job satisfaction as shown in Tables (9) and (10). The most important findings of MDA include the following:

1) There is a strong significant relationship (MCC represents 0.41 in the DF) and a statistically significant relationship at level 0.01 between teaching hospitals of the employees groups and their evaluative attitudes towards job satisfaction at Teaching Hospitals in Egypt (see Table 9).

2) There is a high degree of difference among attitudes of employees towards job satisfaction at Teaching Hospitals in Egypt (the percentage of differentiation was 62\% of DF) (see Table 9).

Table 9. Multiple Discriminant Analysis (MDA) of job satisfaction

\begin{tabular}{|c|c|c|c|c|c|c|c|}
\hline \multicolumn{8}{|c|}{ A- Discriminant Functions } \\
\hline Function & Eigen Values & The $\%$ of Differences & $\mathrm{MCC}$ & Wilks Lambada & Ch-Square & Degree of Sign & Level of Sign \\
\hline 1 & 0.201 & 62.0 & 0.409 & 0.741 & 87.609 & 8 & 0.000 \\
\hline 2 & 0.123 & 38.0 & 0.331 & 0.890 & 34.017 & 3 & 0.000 \\
\hline \multicolumn{8}{|c|}{ B- Classification Matrix } \\
\hline \multicolumn{2}{|c|}{ Groups } & Number & \multicolumn{3}{|c|}{ Predict Member of Groups } & \multicolumn{2}{|r|}{ Total } \\
\hline \multicolumn{2}{|l|}{ Physicians } & 84 & \multicolumn{2}{|c|}{$56(66.7 \%)$} & $14(16.7 \%)$ & $14(16.7 \%)$ & 84 \\
\hline \multicolumn{2}{|l|}{ Nurses } & 183 & \multicolumn{2}{|c|}{$61(33.3 \%)$} & $83(45.4 \%)$ & $39(21.3 \%)$ & 183 \\
\hline \multicolumn{2}{|c|}{ Administrative Staff } & 30 & \multicolumn{2}{|c|}{$7(23.3 \%)$} & $2(6.70 \%)$ & $21(70.0 \%)$ & 30 \\
\hline \multicolumn{2}{|c|}{ Total } & 297 & & & & & 297 \\
\hline \multicolumn{8}{|c|}{ The Percentage of the exact division 53.9\% } \\
\hline
\end{tabular}

3) The accurate classification of employees, according to their evaluative attitudes towards job satisfaction, is $54 \%$, which is not a high percentage. Forty six percentage of the employees are similar (see Table 9).

4) There are four variables relating to job satisfaction. They may discriminate among employees (see Table 10), most importantly, "the employees like their job better than the average worker does" (discrimination coefficients represent 0.80 ), "I would rather be doing another job" (discrimination coefficients represent 0.79), "most days I am enthusiastic about my job" (discrimination coefficients represent 0.75 ), and "I find real enjoyment in my job" (discrimination coefficients represent 0.66).

5) According to the mean of the three groups of employees (see Table 10), differences among them were found. As for physicians, they tend to agree, for example, that I like my job better than the average worker does (with a mean of 3.67). As for nurses, they tend to agree, for example, that I like my job better than the average worker does (with a mean of 4.20). As for administrative staff, they tend to agree, for example, that I find real enjoyment in my job (with a mean of 2.87).

Table 10. The mean among employees concerning job satisfaction

\begin{tabular}{|c|c|c|c|c|c|}
\hline \multirow[t]{2}{*}{ The Variables } & \multicolumn{3}{|l|}{ Mean } & \multirow[t]{2}{*}{ F-Test } & \multirow{2}{*}{$\begin{array}{l}\text { Level } \\
\text { of Sig }\end{array}$} \\
\hline & Group 1 & Group 2 & Group 3 & & \\
\hline 1. I like my job better than the average worker does. & 3.67 & 4.20 & 2.67 & $22.34^{* *}$ & 0.801 \\
\hline 2. I would rather be doing another job. & 3.33 & 2.79 & 2.20 & $11.73^{* *}$ & 0.795 \\
\hline 3. Most days I am enthusiastic about my job. & 3.33 & 3.19 & 1.87 & $13.47^{* *}$ & 0.755 \\
\hline 4. I find real enjoyment in my job. & 3.67 & 4.12 & 2.87 & $14.82^{* *}$ & 0.658 \\
\hline
\end{tabular}

Accordingly, the null hypothesis is rejected because of the value of Wilks Lambda amount to 0.74 (see table 9). Besides, the value of chi-square calculated (87.61) in the free degree of (8) exceeds its table counterpart (20.09) at the statistical significance level of 0.01 (see table 9). On the other hand, it was decided to reject the same null hypothesis of four variables of job satisfaction (5 variables) at the statistical significance level of 0.01, according to the test of univariate $F$ (see table 10).

\subsection{Organizational Cynicism and Organizational Commitment}

The statistical results for answering the fourth question regarding the relationship between organizational cynicism and organizational commitment are investigated. The fourth hypothesis to be tested is:

H4: There is no relationship between organizational cynicism and organizational commitment at Teaching Hospitals in Egypt. 
According to the results of correlation coefficient, there is a statistically significant correlation between the aspects of organizational cynicism and organizational commitment. The correlation of cognitive, affective and behavioral $(-0.018,-0.109$, and -0.409$)$ respectively was found to be significant at 0.05 level. The overall correlation is -0.21 .

Table 11. MRA results for organizational cynicism and organizational commitment

\begin{tabular}{llll}
\hline The Variables of Organizational Cynicism & Beta & $\mathbf{R}$ & $\mathbf{R}^{\mathbf{2}}$ \\
\hline The Cognitive Dimension & $-0.134^{*}$ & -0.018 & 0.0423 \\
The Affective Dimension & $-0.449^{* *}$ & -0.109 & 0.0119 \\
The Behavioral Dimension & $-0.718^{* * *}$ & -0.409 & 0.167 \\
- Multiple Correlation Coefficients (MCC) & 0.497 & \\
- Determination Coefficient (DC) & 0.247 & \\
- The Value of Calculated F' & 32.035 & \\
- Degree of Freedom & 3,293 & \\
- The Value of Indexed F & 3.78 & \\
- Level of Significant & 0.000 & & \\
\hline
\end{tabular}

Notes: $* \mathrm{P}<.05 * * \mathrm{P}<.01$

Depending on MRA, Table 11 presents the type and strength of the relationship between organizational cynicism and organizational commitment. The findings of MRA include the following:

1) According to MCC, there is a statistically significant relationship between organizational cynicism and organizational commitment, $50 \%$.

2) Based on DC, organizational cynicism may interpret $25 \%$ of the total differentiation in organizational commitment.

3) On the basis of MRA, the variables of organizational cynicism providing more explanation of the difference in the level of organizational commitment include the behavioral dimension $(0.72)$, the affective dimension $(0.45)$ and finally the cognitive dimension (0.13).

As a result, the null hypothesis is rejected and the alternative hypothesis is accepted. This is because the model of MRA has shown that there was fundamental relationship between organizational cynicism and organizational commitment at the statistical significance level of 0.01, according to T-Test (See Table 11).

\subsection{Organizational Cynicism and Job Satisfaction}

The statistical results for the relationship between organizational cynicism and job satisfaction are determined. The fifth hypothesis to be tested is:

H5: There is no relationship between organizational cynicism and job satisfaction at Teaching Hospitals in Egypt.

According to the results of correlation coefficient, there is a statistically significant correlation between the aspects of organizational cynicism and job satisfaction. The correlation of cognitive, affective and behavioral ($0.212,-0.333$, and -0.412 ) respectively was found to be significant at 0.05 level. The overall correlation is 0.412 .

Table 12. MRA results for organizational cynicism and job satisfaction

\begin{tabular}{llll}
\hline The Variables of Organizational Cynicism & Beta & $\mathbf{R}$ & $\mathbf{R}^{\mathbf{2}}$ \\
\hline The Cognitive Dimension & $-0.200^{* *}$ & 0.212 & 0.0449 \\
The Affective Dimension & $0.045^{* *}$ & 0.333 & 0.1109 \\
The Behavioral Dimension & $-0.431^{* *}$ & 0.412 & 0.1697 \\
- Multiple Correlation Coefficients & 0.453 & & \\
- Coefficient of Determination & 0.205 & & \\
- The Value of Calculated F & 25.199 & \\
- Degree of Freedom & 3,293 & \\
- The Value of Indexed F & 3.78 & \\
- Level of Significant & 0.000 & & \\
\hline Note: $* * \mathrm{P}<.01$ & &
\end{tabular}


On the basis of MRA, Table (12) presents the type and strength of the relationship between organizational cynicism and job satisfaction. The findings of MRA include the following:

1) According to MCC, there is a statistically significant relationship between organizational cynicism and job satisfaction. It represents $45 \%$.

2) Depending on DC, organizational cynicism may interpret $21 \%$ of the total differentiation in job satisfaction.

3) Based on MRA, the variables of organizational cynicism that better explain the difference in the level of job satisfaction include the behavioral dimension (0.43), the cognitive dimension $(0.20)$, and the affective dimension (0.05).

Accordingly, the null hypothesis is rejected and the alternative hypothesis has been accepted. This is because the model of MRA has shown that there was fundamental relationship between organizational cynicism and job satisfaction at the statistical significance level of 0.01, according to T-Test (See Table 12).

\section{Research Findings}

This study on the effects organizational cynicism on job attitudes at Teaching Hospitals in Egypt has revealed a host of results which are worthy of study and interest. The most important findings are summed up as follows:

1) The researcher was able to determine that differences exist among the employees regarding their evaluative attitudes organizational cynicism, most importantly "the employees' belief that their hospital says one thing and does another", "when the employees think about their hospital, they feel a sense of anxiety", "my hospital expects one thing of its employees, but rewards another", "when I think about my hospital, I experience aggravation", and "we look at each other in a meaningful way with my colleagues when my hospital and its employees are mentioned".

2) The researcher was able to determine that differences exist among the employees regarding their evaluative attitudes towards organizational commitment, most importantly "the lack of work opportunities at other places is one of the most important reasons behind my remaining at this hospital", "I feel strong loyalty and belonging to the family of this hospital", "if I do not have many things to do for myself at this hospital, I will think of working at another place", "I have very few alternatives for work if I decide to leave this hospital", "I owe much to this hospital", and "I feel emotional relation to the hospital where I work".

3) There are differences among the employees regarding their evaluative attitudes towards job satisfaction, most importantly "the employees like their job better than the average worker does", "I would rather be doing another job", "most days I am enthusiastic about my job", and "I find real enjoyment in my job".

4) There is a statistically significant relationship between the dimensions of organizational cynicism (the cognitive dimension, the affective dimension and the behavioral dimension) and organizational commitment at Teaching Hospitals in Egypt.

5) There is a statistically significant relationship between the dimensions of organizational cynicism (the cognitive dimension, the affective dimension and the behavioral dimension) and job satisfaction at Teaching Hospitals in Egypt.

\section{Recommendations}

In the light of previous results, the researcher completed a set of recommendations, the most important of which are:

1) Managers in organizations need to play a more active and vital role in preventing cynicism. Administrators must adopt an open-door policy. This will provide employees the opportunity to freely express their views to managers and administrators without being reprimanded.

2) By learning more about the causes of cynicism, managers can address certain issues that have a tendency to trigger such unwanted behaviors. Having weekly conversations with each employee (i.e., one-on-one) can be a great time and venue for such conversations to take place.

3) Managers need to be more understanding when dealing with all employees. Thus, emotional intelligence trainings for all managers can be effective. "For success in the modern workforce, which is mostly practiced in an increasingly stressful and emotionally taxing environment characterized by high competition, constant transformation and looming uncertainty, emotional intelligence skills provide an advantage" (Kaifi \& Noori, 2010).

4) Management can influence the level of cynicism by ensuring that all successful changes are clearly publicized. No matter how small the change, if it is in the direction intended by management, it should be 
communicated.

5) Organizations must learn to manage values with care to avoid disillusionment and organizational cynicism among employees and recruit people who have lower general cynicism.

6) There are indications of unethical tendencies being less among managers in middle and senior management positions. The role of organizational culture in improving ethicality warrants added attention. Future work might incorporate other research methodologies in measuring organizational cynicism and ethical behavior to further our understanding of this causation.

\section{Limitations and Future Research}

Several limitations of this study should be considered. First, the research population is Teaching Hospitals in Egypt. This sector includes nine Hospitals. The researcher excludes Hospitals in Sohag and Aswan. This explains why the population of this study involves all employees (physicians, nurses, and administrative staff). Also, the present study has drawn on the questionnaire method for collecting primary data necessary for the study. The questionnaire list is interested in recognizing organizational cynicism and organizational attitudes.

There are several areas for possible future research. First, it will be useful to investigate the relationship between organizational cynicism and job attitudes at larger organizations. Second, a comparative analysis between private and public hospitals may be made. This subject may be applied in different fields other than the health sector (e.g., military, security, and educational organizations, etc.). Future researches also need to investigate the relationship between organizational cynicism and burnout of employees. Finally, future studies need to examine the relationship between organizational cynicism and organizational change.

\section{Conclusion and Implications}

For individual managers, the practical implications begin with the recognition that employee cynicism is an important attitude with significant consequences. Within the scope of the study, the concepts of organizational cynicism and job attitudes are generated by trying to point out the levels of organizational cynicism among the Teaching Hospitals in Egypt. It has been concluded that there are differences among the employees regarding their evaluative attitudes towards organizational cynicism and job attitudes. However the cognitive, affective, and behavioral dimensions of organizational cynicism have a significant effect on job attitudes.

Since organizational cynicism is associated with many other concepts such as job satisfaction and organizational commitment, managers should deepen the perception of organizational justice that can be realized without spending much effort and resources. In organizations with a high sense of justice, motivation and internal loyalty, employees are more likely to be more loyal to their work and organizations.

Organizational trainings should become the norm in many organizations where managers discuss specific attitudes that affect the organization's culture while emphasizing both the short-term and long-term implications of organizational cynicism. In order for an organization to be competitive, it becomes imperative for its human resources to focus on creativity, innovativeness, unity, and efficacy. Thus, distractions of organizational cynicism can be disastrous for an organization and the culprits should be reprimanded.

Quarterly surveys should also be used to gauge how employees are feeling so managers can create a healthier environment for all employees. Needless to say, stress can be the root cause of organizational cynicism and stress can come in many different forms and from many different internal and external factors. Future researchers should consider investigating the relationship between stress and organizational cynicism.

\section{References}

Abraham, R. (2000). Organizational Cynicism: Bases and Consequences. Genetic, Social, and General Psychology Monographs, 126(3), 269-292.

Agho, A., Mueller, C., \& Price, J. (1993). Determinants of Employee Job Satisfaction: An Empirical Test of a Causal Model. Human Relation, 46, 1007-1027. http://dx.doi.org/10.1177/001872679304600806

Allen, N., \& Meyer, J. (1990). The Measurement and Antecedents of Affective, Continuance and Normative Commitment to the Organization. Journal of Occupational Psychology, 63, 1-18. http://dx.doi.org/10.1111/j.2044-8325.1990.tb00506.x

Andersson, L. (1996). Employee Cynicism: An Examination Using a Contract Violation Framework. Human Relations, 1397-1398.

Babakus, E., Cravens, D., Johnston, M., \& Moncrief, W. (1999). The Role of Emotional Exhaustion in Sales Force Attitude and Behavior Relationships. Journal of the Academy of Marketing Science, 27(1), 58-70. 
http://dx.doi.org/10.1177/0092070399271005

Barefoot, J., Dodge, K., Peterson, B., Dahlstrom, W., \& Williams, R. (1989). The Cook-Medley Hostility Scale. Item Content and Ability to Predict Survival. Psychosomatic Medicine, 51, 46-57.

Bateman, T., \& Strasser, S. (1984). A longitudinal Analysis of the Antecedents of Organizational Commitment. Academy of Management Journal, 21, 95-112. http://dx.doi.org/10.2307/255959

Bernerth, J., Armenakis, A., Feild, H., \& Walker, H. (2007). Justice, Cynicism, and Commitment: A Study of Important Organizational Change Variables. The Journal of Applied Behavioral Science, 43(3), 303-326. http://dx.doi.org/10.1177/0021886306296602

Bhuian, S., \& Menguc, B. (2002). An Extension and Evaluation of Job Characteristics, Organizational Commitment and Job Satisfaction in an Expatriate, Guest Worker, Sales Setting. Journal of Personal Selling \& Sales Management, 22(1), 1-11.

Boles, J., Ramana, M., Brian, R., \& John, A. (2007). The Relationship of Facets of Salesperson Job Satisfaction with Affective Organizational Commitment. Journal of Business \& Industrial Marketing, 22(5), 311-321. http://dx.doi.org/10.1108/08858620710773440

Brandes, P., Dharwadkar, R., \& Dean, J. (1999). Does Employee Cynicism Matter? Employee and Supervisor Perspectives on Work Outcomes. Paper Presented at the Eastern Academy of Management, Philadelphia.

Brewer, A. (1996). Developing Commitment Between Managers and Employees. Journal of Managerial Psychology, 11(4), 24-34. http://dx.doi.org/10.1108/02683949610117599

Chang, L., Shih, C., \& Lin, S. (2010). The Mediating Role of Psychological Empowerment on Job Satisfaction and Organizational Commitment for School Health Nurses: A Cross-Sectional Questionnaire Survey. International Journal of Nursing Studies, 47(4), 427-433. http://dx.doi.org/10.1016/j.ijnurstu.2009.09.007

Cole, M., Brunch, H., \& Vogel, B. (2006). Emotion as Mediators of the Relations between Percived Supervision Support and Psychological Hardiness on Employee Cynicism. Journal of Organizational Behavior, 27, 463-484. http://dx.doi.org/10.1002/job.381

Daniel, W. (1999). Biostatistics: A Foundation For Analysis in the Health Sciences (7th ed.). New York: John Wiley \& Sons.

Dean, J., Brandes, P., \& Dharwadkar, R. (1998). Organizational Cynicism. The Academy of Management Review, 23(2), 341-352.

Desselle, S. (1998). New York State Pharmacists: Relationship Between Job Satisfaction, Workplace Climate, Commitment, and Providing Pharmaceutical Care, New York State Pharmacist Century II. (Vol. 72, pp. 27-29).

Dewettinck, K., \& Van Ameijde, M. (2011). Linking Leadership Empowerment Behavior to Employee Attitudes and Behavioral Intentions: Testing the Mediating Role of Psychological Empowerment. Personal Review, 40(3), 284-305. http://dx.doi.org/10.1108/00483481111118621

Dunham, R., Grube, J., \& Castaneda, M. (1994). Organizational Commitment: The Utility of an Integrative Definition. Journal of Applied Psychology, 79(3), 370-380. http://dx.doi.org/10.1037/0021-9010.79.3.370

Elbert, R., \& Griffin, R. (2005). Business Essentials (5th ed.). New Jersey: Pearson Education.

Finn, C. (2001). Autonomy: An Important Component for Nurses' Job Satisfaction. International Journal of Nursing Studies, 38(3), 349-57. http://dx.doi.org/10.1016/S0020-7489(00)00065-1

Fisher, C., \& Locke, E. (1992). The New Look in Job Satisfaction Research and Theory. In C. Cranny, P. Smith \& E. Stone (Eds.), Job Satisfaction: How People Feel about Their Jobs and How it Affects their Performance. New York: Lexington Books.

Greenberg, J., \& Baron, R. (2003). Behaviour in Organizations: Understanding and Managing the Human Side of Work (8th ed.). Upper Saddle River: Pearson Education, Inc.

Griffeth, R., Gaertner, S., \& Sager, J. (1999). Taxonomic Model of Withdrawal Behaviors: The Adaptive Response Model. Human Resources Management Review, 9, 577-590. http://dx.doi.org/10.1016/S1053-4822(99)00034-0

Hardigan, P., \& Carvajal, M. (2001). The Influence of Positive and Negative Affectivity on Reported Job Satisfaction Among Practicing Pharmacists. Journal of Pharmaceutical Marketing \& Management, 13(4), 57-71. http://dx.doi.org/10.3109/J058v13n04_04 
Hong, L., While, A., \& Barriball, K. (2005). Job Satisfaction Among Nurses: A Literature Review. International Journal of Nursing Studies, 42(2), 211-227. http://dx.doi.org/10.1016/j.ijnurstu.2004.09.003

Hussami, M. (2008). A Study of Nurses' Job Satisfaction: The Relationship to Organizational Commitment, Perceived Organizational Support, Transactional Leadership, Transformational Leadership and Level of Education. European Journal of Scientific Research, 22(2), 286-295.

Ince, M., \& Turan, S. (2011). Organizational Cynicism as A Factor that Affects the Organizational Change in the Process of Globalization and An Application in Karaman's Public Institutions. Journal of Economics, Finance and Administrative Sciences, 37, 104-121.

Ivancevich, J., \& Matteson, M. (2002). Organizational Behaviour and Management (6th ed.). New York: McGraw-Hill.

Jernigan, I., Beggs, J., \& Kohut, G. (2002). Dimensions of Work Satisfaction as Predictor of Commitment Type. Journal of Managerial Psychology, 17(7), 546-579. http://dx.doi.org/10.1108/02683940210444030

Kaifi, B. (2013). Organizational Behavior: Managing and Leading Organizations. Tamarac, FL: Llumina Press.

Kalağan, G. (2009). Araştırma Görevlilerinin Örgütsel Destek Algıları İle Örgütsel Sinizm Tutumları Arasındaki İlişki, Yayınlanmamış Yüksek Lisans Tezi, Akdeniz Üniversitesi Sosyal Bilimler Enstitüsü.

Koretz, G. (2003). Hate Your Job? Join the Club. Business Week.

LaLopa, J. (1997). The Prediction of Organizational Commitment and Turnover in Resort Jobs. Journal of Hospitality and Tourism Research, 21, 11-26. http://dx.doi.org/10.1177/109634809702100202

Lane, K., Esser, J., Holte, B., \& McCusker, M. (2010). A Study of Nurse Faculty Job Satisfaction in Community Colleges in Florida. Teaching and Learning in Nursing, 5(1), 16-26. http://dx.doi.org/10.1016/j.teln.2009.05.001

Meyer, J., \& Allen, N. (1988). Links between Work Experience and Organizational Commitment During the First Year of Employment: A Longitudinal Analysis. Journal of Occupational Psychology, 61, 195-209. http://dx.doi.org/10.1111/j.2044-8325.1988.tb00284.x

Meyer, J., \& Allen, N. (1991). A Three Component Conceptualization of Organizational Commitment. Human Resource Management Review, 11(1), 61-89. http://dx.doi.org/10.1016/1053-4822(91)90011-Z

Meyer, J., Allen, N., \& Smith, C. (1993). Commitment to Organizations and Occupations: Extension and Test of a Three-Component Conceptualization. Journal of Applied Psychology, 78(4), 538-551. http://dx.doi.org/10.1037/0021-9010.78.4.538

Meyer, J., Stanley, D., Herscovitch, L., \& Topolnytsky, L. (2002). Affective, Continuance, and Normative Commitment to the Organization: A Meta-Analysis of Antecedents, Correlates, and Consequences. Journal of Vocational Behavior, 61, 20-52. http://dx.doi.org/10.1006/jvbe.2001.1842

Mowday, R., Porter, L., \& Steers, R. (1982). Employee Organization Linkages: The Psychology of Commitment, Absenteeism, and Turnover. New York: Academic Press.

Mowday, R., Steers, R., \& Porter, L. (1979). The Measurement of Organizational Commitment. Journal of Vocational Behavior, 14(3), 224-247. http://dx.doi.org/10.1016/0001-8791(79)90072-1

Nair, P., \& Kamalanabhan, J. (2010). The Impact of Cynicism on Ethical Intentions of Indian Managers: The moderating Role of Seniority. Journal of International Business Ethics, 3(1), 4-29.

Namasivayama, K., \& Zhaob, X. (2007). An Investigation of the Moderating Effects of Organizational Commitment on the Relationships Between Work Family Conflict and Job Satisfaction Among Hospitality $\begin{array}{llll}\text { Employees in India. Tourism } & \text { Management, 28(5), }\end{array}$ http://dx.doi.org/10.1016/j.tourman.2006.09.021

Netemeyer, R., Boles, J., McKee, D., \& McMurrian, R. (1997). An Investigation Into the Antecedents of Organizational Citizenship Behaviors in a Personal Selling Context. $J$ Mark., 61(3), 85-98. http://dx.doi.org/10.2307/1251791

Noel, M., Hammel, R., \& Bootman, J. (1982). Job Satisfaction Among Hospital Pharmacy Personnel. American Journal of Health-System Pharmacy, 39(4), 600- 606.

Özgener, Ş., Öğüt, A., \& Kaplan, M. (2008). İşgören-İşveren İlişkilerinde Yeni Bir Paradigma: Örgütsel Sinizm. In İ̧̧inde Özdevecioğlu, M. ve Karadal, H., (Eds.), Örgütsel Davranışta Seçme Konular: Organizasyonların Karanlık Yönleri ve Verimlilik Azaltıcı Davranışlar (pp. 53-72). Ankara: İlke Yayınevi. 
Ozler, E., Derya, A., \& Ceren, A. G. (2011). A Research to Determine the Relationship between Organizational Cynicism and Burnout Levels of Employees in Health Sector. Business and Management Review, 1(4), 26-38.

Özler, E., Derya, A., Giderler, C., \& Şahin, D. (2010). Örgütlerde Sinizm Güvensizlikle Mi Bulaşır? Organizasyon ve Yönetim Bilimleri Dergisi, 2(2), 47-57.

Porter, L., Crampon, W., \& Smith, F. (1976). Organizational Commitment and Managerial Turnover: A Longitudinal Study. Organizational Behaviour and Human Performance, 15(1), 87-98. http://dx.doi.org/10.1016/0030-5073(76)90030-1

Price, J. (2001). Reflections on the Determinants of Voluntary Turnover. International Journal of Manpower, 22(7), 600-624. http://dx.doi.org/10.1108/EUM0000000006233

Price, J., \& Mueller, C. (1981). Professional Turnover: The Case of Nurses. Luce, Bridgeport CT. http://dx.doi.org/10.1007/978-94-011-8016-0

Price, J., \& Mueller, C. (1986). Absenteeism and Turnover among Hospital Employees. Greenwich CT: JAI Press.

Rahim, A. (1982). Demographic Variables in General Job Satisfaction in a Hospital: A Multivariate Study. Percept and Motor Skills, 55(3), 711-719. http://dx.doi.org/10.2466/pms.1982.55.3.711

Raju, P., \& Srivastava, R. (1994). Factors Contributing to Commitment to the Teaching Profession. International Journal of Educational Management, 8(5), 7-13. http://dx.doi.org/10.1108/09513549410065684

Reichers, A., Wanous, J., \& Austin, J. (1997). Understanding and Managing Cynicism About Organizational Change. Academy of Management Executive, 11(1), 48-59.

Riggio, R. (2009). Introduction to Industrial/Organizational Psychology. London: Pearson.

Rothmann, S., \& Coetzer, E. (2002). The Relationship Between Personality Dimensions and Job Satisfaction. Business Dynamics, 11(1), 29-42.

Saari, L., \& Judge, T. (2004). Employee Attitudes and Job Satisfaction. Human Resource Management, 43(4), 395-407. http://dx.doi.org/10.1002/hrm.20032

Schermerhorn, J., Hunt, J., \& Osborn, R. (1997). Organizational Behavior. New York: J.W. and Sons, Inc.

Schwepker, C. (2001). Ethical Climate's Relationship to Job Satisfaction, Organizational Commitment, and Turnover Intention in the Sales Force. Journal of Business Research, 54, 39-52. http://dx.doi.org/10.1016/S0148-2963(00)00125-9

Sempane, M., Rieger, H., \& Roodt, G. (2002). Job Satisfaction in Relation to Organizational Culture. South African Journal of Industrial Psychology, 28(2), 23-30.

Sharma, J., \& Bajpai, N. (2010). Organizational Commitment and its Impact on Job Satisfaction of Employees: A Comparative Study in Public and Private Sector in India. International Bulletin of Business Administration, 9, 7-19.

Silverthorne, C. (2004). The Impact of Organizational Culture and Person Organization Fit on Organizational Commitment and Job Satisfaction in Taiwan. The Leadership and Organization Development Journal, 25(7), 522-599. http://dx.doi.org/10.1108/01437730410561477

Spector, P. (1997). Job Satisfaction: Application, Assessment, Causes and Consequences. California: Sage.

Stanley, D., Meyer, J., \& Topolnytsky, L. (2005). Employee Cynicism and Resistance to Organizational Change. Journal of Business and Psychology, 19(4), 429-459. http://dx.doi.org/10.1007/s10869-005-4518-2

Stewart, J. (1983). Hospital Pharmacists' Job Satisfaction: A Review of the Data. Topics in Hospital Pharmacy Management, 3(1), 1-9.

Vidal, M., Valle, R., \& Aragón, B. (2007). Antecedents of Repatriates’ Job Satisfaction from Spanish Repatriated $\begin{array}{lllll}\text { Managers. Journal of } \quad \text { Business } & \text { Research, } & 60(12), & 1281 .\end{array}$ http://dx.doi.org/10.1016/j.jbusres.2007.05.004

Wagner, C. (2007). Organizational Commitment As A Predictor Variable in Nursing Turnover Research: Literature Review. Journal of Advanced Nursing, 60, 235-247. http://dx.doi.org/10.1111/j.1365-2648.2007.04421.x

Wong, C., Wong, Y., Hui, C., \& Law, K. S. (2001). The Significant Role of Chinese Employees' Organizational 
Commitment: Implications for Managing Employees in Chinese Societies. Journal of World Business, 36(3), 326-340. http://dx.doi.org/10.1016/S1090-9516(01)00058-X

Yang, J. (2009). Antecedents and Consequences of Job Satisfaction in the Hotel Industry. International Journal of Hospital Management, 29(4), 609-619. http://dx.doi.org/10.1016/j.ijhm.2009.11.002

Yang, J., \& Mossholder, K. (2010). Examining the Effects of Trust in Leaders: A Bases-and-Foci Approach. Leadership Quarterly, 21(1), 50-63. http://dx.doi.org/10.1016/j.leaqua.2009.10.004

\section{Copyrights}

Copyright for this article is retained by the author(s), with first publication rights granted to the journal.

This is an open-access article distributed under the terms and conditions of the Creative Commons Attribution license (http://creativecommons.org/licenses/by/3.0/). 